\title{
Analisis Kontrastif Proses Morfofonologi Bahasa Jawa dan Bahasa Arab
}

\author{
Muhammad Afif Amrulloh \\ Universitas Islam Negeri (UIN) Raden Intan Lampung \\ afif.amrulloh@radenintan.ac.id
}

\begin{abstract}
Mastery of a foreign language is very important. The increasingly close relations between nations requires the availability of foreign language skills to meet communication needs. Moreover, there are often difficulties or difficulties experienced by foreign language learners with a mother tongue background who have a language system that is not the same as a foreign language system. The purpose of knowing the process morfofonemik in the Java Language and the Arabic language. Types of library research or library research, which takes a data source in the literature. This study includes the type of qualitative research. The research explained the data and then analyzed systematically. The results and findings of the study that the process of morphophonology in the Java language occur because of the appearance of phonemes, pelesapan phonemes, leaching phonemes and shifting phonemes. Whereas in Arabic occurs phonemeal dissolution, phoneme changes, the addition of phonemes and shifting phonemes. The equation of the process morfofonemik between the two languages, namely the same-the same happened phoneme dissolution, while the difference is in the Arabic language does not occur appearance and leaching phonemes as in the language of Java. Implications this study has contributed to the ease of learning in the mastery of foreign languages by learners of a foreign language, namely Arabic.
\end{abstract}

Keywords: analysis contrastive, morphology, phonology

\begin{abstract}
Abstrak
Kebutuhan terhadap penguasaan bahasa asing merupakan hal yang sangat penting. Semakin erat interaksi antarbangsa seirama dengan ketersediaan kemampuan berbahasa asing guna memenuhi kebutuhan komunikasi. Terlebih seringkali dijumpai kesulitan atau kesusahan yang dialami oleh para pembelajar bahasa asing dengan berlatar belakang bahasa ibu yang memiliki sistem bahasa yang tidak sama dengan sistem bahasa asing. Penelitian ini bertujuan mengetahui perbandingan proses morfofonemik dalam Bahasa Jawa
\end{abstract}


dan bahasa Arab. Jenis penelitian pustaka atau library research, yang mengambil sumber data secara kepustakaan. Penelitian kualitatif yang memaparkan data-data dan kemudian dianalisis secara sistematis. Hasil dan temuan penelitian bahwa proses morfofonemik dalam bahasa Jawa terjadi lantaran adanya pemunculan fonem, pelesapan fonem, peluluhan fonem dan pergeseran fonem. Morfofonemik dalam bahasa Arab terjadi secara pelesapan fonem, perubahan fonem, penambahan fonem dan pergeseran fonem. Persamaan proses morfofonemik antar kedua bahasa itu yaitu samasama terjadi pelesapan fonem, sedangkan aspek perbedaanya adalah pada bahasa Arab tidak terjadi pemunculan dan peluluhan fonem seperti pada bahasa Jawa. Implikasi kajian ini memiliki kontribusi terhadap kemudahan pembelajaran penguasaan bahasa asing oleh para pembelajar bahasa asing yaitu bahasa Arab.

Kata Kunci: analisis kontrastif, morfologi, fonologi

\section{Pendahuluan}

Sudah menjadi keniscayaan bahwa kehadiran bahasa sangat dibutuhkan oleh manusia. Keberadaannya tidak dapat terpisahkan, ibarat seperti dua mata koin yang menggambarkan interaksi di antara keduanya. Manusia tidak dapat hidup tanpa bahasa, dengan bahasa tersebut mampu terjalin komunikasi yang baik antar bangsa dan segala kebutuhan dan kelangsungan hidup dapat terpenuhi. Oleh karena itu, penguasaan bahasa ini menjadi sangat mendasar atau fundamental dalam menjalin pergaulan antar bangsa.

Penguasaan bahasa tidak hanya sebatas pada bahasa ibu atau bahasa pertama saja, akan tetapi juga mencakup penguasaan terhadap bahsa asing atau bahasa kedua. Maksud bahasa asing yaitu bahasa kedua yang dipelajari oleh penutur bahasa setelah bahasa ibu. Sedangkan bahasa ibu adalah bahasa yang dipelajari atau digunakan ketika pertama kali menggunakan bahasa, yaitu ketika masih kecil. Misalnya anak kecil yang dibesarkan dari keluarga di lingkungan berbahasa Jawa, maka bahasa ibu yang ia miliki adalah bahasa Jawa.

Penggunaan bahasa sudah dimulai oleh setiap manusia sejak kecil. Ketika awal-awal pertumbuhannya dikenalkan dengan berbagai lambang bunyi atau nama-nama benda di sekitar. Kemudian terus berkembang sampai akhirnya menguasai bahasa pertamanya yaitu bahasa ibu. Bahasa ini dimaksudkan untuk proses komunikasi antar sesama dalam rangka memenuhi kebutuhan hidup manusia.

Seperti halnya manusia yang merupakan makhluk sosial tidak dapat terlepas dari peran orang lain di sekitar melalui alat komunikasi yaitu bahasa. Pada tahap berikutnya, sejalan dengan pertumbuhan dan perkembangan manusia maka kehidupan berbahasanya juga semakin meningkat. Baik 
peningkatan pada aspek kualitas maupun kuantitas. Secara kualitas, pola struktur kalimat yang dihasilkan semakin tertata rapi. Demikian pula dari segi kuantitas perbendaharaan kata yang dimiliki juga semakin lengkap.

Bahasa seperti yang sudah dipahami bahwa ia merupakan sebuah sistem lambang bunyi yang arbitrer dan dituturkan oleh suatu komunitas tertentu dalam memenuhi kebutuhan interaksi komunikasi antar sesame. ${ }^{1}$ Sebagai sebuah sistem, setiap bahasa memiliki keteraturan atau kaedah yang dimiliki oleh bahasa sehingga dapat dimengerti oleh penuturnya. Tentunya kaedah atau sistem yang berlaku dalam suatu bahasa tersebut.

Misalnya mencakup segala komponen pembentuk gramatika atau struktur kalimat. Kalimat yang terstruktur secara sistematis akan mampu dipahami oleh para penuturnya sehingga dapat digunakan untuk kebutuhan komunikasi di antara sesama para penutur bahasa. Namun berlaku sebaliknya, jika suatu bahasa tidak terstruktur secara sistematis sesuai dengan kaedah atau aturan yang berlaku, maka sudah bisa dipastikan bahasa tersebut tidak dapat digunakan oleh suatu komunitas penutur bahasa tertentu.

Hubungan antarbangsa yang berbeda sistem bahasanya menghasilkan usaha untuk saling mempelajari bahasa. Setiap bahasa memiliki sistem bahasa yang tidak sama. Seperti anatara sistem bahasa yang dimiliki oleh bahasa Arab dan bahasa Jawa. Masing-masing menggunakan kaedah atau aturan tata bahasa yang berbeda dan berlaku pada komunitas tersebut. Terkadang terdapat persamaan ataupun perbedaan dalam pola penyusunan struktur kalimat tertentu antar bahasa Arab dengan Bahasa Jawa.

Antara bahasa ibu atau Bahasa Jawa tidak sama dengan bahasa kedua atau bahasa Arab. Keduanya memiliki karakteristik dan aturan tersendiri. Ketika kedua sistem bahasa tersebut saling berkontak maka terjadilah pergulatan antara bahasa pertama yang sudah digunakan dengan bahasa kedua atau bahasa asing yang baru dipelajari. Setiap bahasa memiliki sistem fonologi yang tidak sama. Misalnya sistem fonologi pada bahasa Jawa dengan bahasa Arab jelas berbeda. Perbedaan ini dikarenakan adanya beberapa fitur fonetik bahasa pertama yang tidak ada pada fitur fonetik bahasa Arab. ${ }^{2}$

Tentunya hal ini akan memberikan kesulitan tersendiri kepada para pembelajar bahasa dalam menguasai bahasa kedua tersebut. Sehingga dalam mempelajari bahsa asing tidak jarang pula terjadi kesalahan berbahasa. Baik kesalahan pada tataran fonologi, morfologi, sintaksis atau bahkan semantik. Dengan berlatar belakang bahasa warisan atau bahasa ibu berupa Bahasa Jawa,

${ }^{1}$ Farida Kusuma Dimyati, "Proses Morfofonemik Dalam Bahasa Inggris Dan Bahasa Gorontalo (Suatu Analisis Kontrastif)," 2014.

2 Suherman, "Perubahan Fonologis Kata-Kata Serapan Bahasa Sunda Dari Bahasa Arab: Studi Kasus Pada Masyarakat Sunda Di Jawa Barat, Indonesia," Sosiohumanika 5, no. 1 (2012). 
maka tidak sedikit dijumpai kesulitan dalam mempelajari bahasa asing (bahasa Arab). Karena bahasa yang diketahui lebih dahulu memberikan pengaruh terhadap bahasa sasaran yang sedang dipelajari saat berikutnya. Terlebih lingkungan di sekitar juga memiliki peran yang besar dalam membentuk suatu bunyi atau bahasa. ${ }^{3}$

Misalnya terjadi interferensi atau interaksi berbahasa ketika dua bahasa yang berbeda berkontak. Sehingga secara otomatis dapat muncul peristiwa alih kode, pinjaman linguistik dan sebagainya. Oleh karena itu, diperlukan trobosan untuk memecahkan persoalan tersebut. Salah satunya yaitu dengan menggunakan analisis kontrastif. Analisis kontrastif atau disingkat dengan anakon ini dilakukan dengan membandingkan antara bahasa Arab dengan Bahasa Jawa. Khusus untuk kajian ini dilakukan dengan membandingkan proses morfofonemik antara bahasa sumber (Bahasa Jawa) dengan bahasa sasaran (bahasa Arab). Pada bahasa Arab khususnya pada kata yang memiliki kaidah perubahan morfofonemik secara teratur.

Bahkan menurut Jiah Fauziah dalam tulisannya yang berjudul Fitur-fitur Fonologis Penggunaan Elemen-elemen Bahasa Arab dalam Komunikasi Masyarakat Keturunan Arab Surakarta, menjelaskan bahwa terjadinya perubahan fonologis banyak disebabkan oleh faktor artikulasi. Artinya bahwa perubahan fonologis ini lebih ditekankan pada aspek memudahkan artikulasi. Kecenderungan penutur bahasa untuk menyederhanakan dan memudahkan pengucapan suatu bunyi pada sistem bahasa. Seperti penelitian yang dilakukan oleh Gunarsih tahun 2002 yang berjudul "Proses Morfofonemik dalam Bahasa Jawa dan Bahasa Arab (Sebuah Analisis Kontrastif)" menjelaskan bahwa proses morfofonemik dalam Bahasa Jawa terjadi karena adanya afiksasi, seperti prefiks, infiks, sufiks dan komposisi. Sedangkan proses morfofonemik dalam bahasa Arab terjadi secara konjugasi.

Kesamaan antara kedua bahasa tersebut dalam proses morfofonemik yaitu sama-sama terjadi dalam satu kata. Adapun perbedaan antara keduanya yaitu proses morfofonemik dalam Bahasa Jawa karena proses imbuhan pada morfem bebas, sedangkan dalam bahasa Arab dikenal dengan nama i'lal dan ibdal. Probelem yang sering dihadapi oleh para siswa adalah dalam mengi'lalkan dan mengkategorikan lafal, sehingga diperlukan metode yang paling efektif dalam mempelajari morfofonemik bahasa Arab yaitu dengan drill atau latihanlatihan yang sesuai dengan kaedeh yang benar. ${ }^{4}$

Penguasaan terhadap bahasa asing merupakan hal yang sangat penting. Semakin erat hubungan antarbangsa menuntut ketersediaan kemampuan

3 Muhammad Afif Amrulloh, "Taghyiru Soutiyat Al-Lughah Al-'Arabiyyah AlMusta'arah Fi Al-Lughah Al-Jawiyyah," Al Bayan: Jurnal Jurusan Pendidikan Babasa Arab 8, no. 2 (2016).

${ }^{4}$ Gunarsih, "Proses Morfofonemik Dalam Bahasa Indonesia Dan Bahasa Arab" (IAIN Sunan Kalijaga Yogyakarta, 2002). 
berbahasa asing untuk memenuhi kebutuhan komunikasi. Terlebih seringkali dijumpai kesulitan atau kesusahan yang dialami oleh para pembelajar bahasa asing dengan bertalar belakang bahasa ibu yang memiliki sistem bahasa yang tidak sama dengan sistem bahasa asing. Oleh karena itu, peneliti tertarik untuk membahas kajian tentang analisis kontrastif proses morfofonemik antara Bahasa Jawa dengan bahasa Arab. Dengan demikian, diharapkan akan mampu menyelesaikan persoalan linguistik yang menjadi kendala dalam mempelajari bahasa target.

Penelitian tentang analisis kontrastif proses morfofonemik bahasa Jawa dan bahasa Arab ini dilakukan oleh peneliti dengan menggunakan jenis penelitian pustaka atau library research. Penelitian yang mengambil sumber data secara kepustakaan. Data diperoleh dengan menggunakan teknik dokumentasi, yaitu berdasarkan pustaka, baik berupa buku, jurnal maupun hasil penelitian lain yang terkait dengan kajian pembahasan. Penelitian ini termasuk jenis penelitian kualitatif. Penelitian yang memaparkan data-data dan kemudian dianalisis secara sistematis. Adapun analisis data menggunakan penelitian deskriptif yang memaparkan berbagai data atau permasalahan dan kemudian selanjutnya dianalisis dengan analisis kontrastif. Analisis yang membandingkan antara bahasa Arab (bahasa kedua) dengan Bahasa Jawa (bahasa ibu). Penelitian ini menggunakan teori morfofologi untuk membahas tentang proses morfofologi antara bahasa Arab dengan Bahasa Jawa.

Melalui kajian ini, diharapkan dapat diketahui proses morfofonemik pada bahasa Jawa dan bahasa Arab. Selain itu, dapat diketahui pula perbandingan di antara keduanya melalui analisis kontrastif. Kajian ini memiliki urgensi terhadap kontribusi pembelajaran bahasa asing sehingga mampu memberikan kemudahan dalam penguasaan bahasa kedua. Kajian analisis kontrastif ini berbeda dengan kajian yang sudah-sudah, memiliki novelty melalui perbandingan tema kajian ini dengan kajian yang lalu bahwa bahasa Jawa sebagai bahasa ibu bagi penutur yang banyak di wilayah Jawa sehingga diharapkan mampu membantu problem penguasaan bahasa asing oleh para penutur tersebut.

\section{Pembahasan}

\section{Proses Morfofonemik Bahasa Jawa}

Morfofonemik merupakan perpaduan dua cabang dalam kajian linguistik, yaitu morfologi dan fonologi atau morfologi dan fonemik. ${ }^{5}$ Fenomena ini juga terjadi pada bahasa Jawa. Bahasa Jawa merupakan bahasa daerah yang memiliki penutur sebagain besar di wilayah Jawa Tengah, DIY dan Jawa Timur

5 Rama Ulun Sundasewu, "Analisis Kontrastif Perubahan Fonem Pada Proses

Reduplikasi Dalam AHASBahasa Jepang Dan Bahasa Indonesia : Kajian Morfofonemik,” Jurnal Ilmu Pendidikan Dan Pengajaran 2, no. 2 (2015). 
yang termasuk bahasa aglutinatif atau bahasa yang kaya akan morfologi. ${ }^{6}$ memeiliki keanekaragaman perubahan bunyi fonem yang tidak sedikit. Perubahan bunyi fonem ini adalah hasil yang ditimbulkan oleh proses morfologi atau pertemuan antar morfem. Perubahan fonem ini bisa dilakukan dengan proses morfologi seperti afiksasi, reduplikasi atau komposisi. Beberapa proses morfofonemik yang terjadi pada bahasa Jawa yaitu sebagai berikut:

\section{a. Pemunculan Fonem}

Yaitu adanya fonem atau bunyi baru yang muncul pada proses morfologi. Fonem baru ini muncul di dalam pembentukan suatu kata yang awalnya tidak ada. Morfofonemik pada proses pengimbuhan ater-ater atau prefiks pan- pada kata dasar berawalan vokal /a/ yaitu aba, abdi, absah, abur, adol, adu dan ajar akan memunculkan bunyi atau fonem baru berupa fonem /g/ yang pada awalnya tidak muncul di kata dasar tersebut.

\begin{tabular}{|l|l|l|}
\hline Perfiks & $\begin{array}{l}\text { Kata } \\
\text { Dasar }\end{array}$ & Morfofonologi \\
\hline Pan- & Aba & Pangaba \\
\hline Pan- & Abdi & Pangabdi \\
\hline Pan- & Absah & Pangabsah \\
\hline Pan- & Abur & Pangabur \\
\hline Pan- & Adol & Pangadol \\
\hline Pan- & Adu & Pangadu \\
\hline Pan- & Ajar & Pangajar \\
\hline
\end{tabular}

Tabel 1. Morfofonemik perfiks pan-

Morfofonemik dengan menggunakan konfiks atau imbuhan bebarengan berupa $p a$ - an pada kata dasar berawal konsonan /b/ yaitu babag, babar, babat, bacok, bales, bantah, barut, dan batal akan memunculkan bunyi atau fonem /m/ yang pada kata dasar sebelumnya tidak ada fonem tersebut.

\begin{tabular}{|l|l|l|l|}
\hline Konfiks & Kata Dasar & Konfiks & Morfofonologi \\
\hline$P a-$ & Babag & $a n$ & Pambabagan \\
\hline$P a-$ & Babar & $a n$ & Pambabaran \\
\hline$P a-$ & Babat & $a n$ & Pambabatan \\
\hline$P a-$ & Bacok & $a n$ & pambacokan \\
\hline$P a-$ & Bales & $a n$ & Pambalesan \\
\hline
\end{tabular}

${ }^{6}$ Agus Subiyanto, "Proses Fonologis Bahasa Jawa: Kajian Teori Optimalitas," Bahasa Dan Seni, no. 2 (2010): 154-65. 


\begin{tabular}{|l|l|l|l|}
\hline$P a-$ & Bantah & an & pambantahan \\
\hline$P a-$ & Barut & an & Pambaruan \\
\hline$P a-$ & Batal & an & Pambatalan \\
\hline
\end{tabular}

Tabel 2. Morfofonemike Konfiks pa-an

Morfofonemik pada proses pengimbuhan sufiks - $i$ pada kata dasar berakhiran vokal /a/ dan /i/ yaitu baya, bekti, bela, beya, bantu, conto dan dadi akan memunculkan bunyi atau fonem baru berupa fonem /n/ yang pada awalnya tidak muncul di kata dasar tersebut.

\begin{tabular}{|l|l|l|}
\hline Sufiks & $\begin{array}{l}\text { Kata } \\
\text { Dasar }\end{array}$ & Morfofonologi \\
\hline$-i$ & Baya & Bayani \\
\hline$-i$ & Bekti & Bektini \\
\hline$-i$ & Bela & Belani \\
\hline$-i$ & Beya & Beyani \\
\hline$-i$ & Bantu & Bantuni \\
\hline$-i$ & Conto & Contoni \\
\hline$-i$ & Dadi & Dadini \\
\hline
\end{tabular}

Tabel 3. Morfofonemik Sufiks -i

Morfofonemik pada proses pengimbuhan sufiks -ake pada kata dasar berakhiran vokal /e/ dan /o/ yaitu delolo, foto, gawe, gedhe, bage, blonyo dan bojo akan memunculkan bunyi atau fonem baru berupa fonem / $/$ yang pada awalnya tidak muncul di kata dasar tersebut.

\begin{tabular}{|l|l|l|}
\hline Sufiks & Kata Dasar & Morfofonologi \\
\hline -ake & Delolo & Delolokake \\
\hline -ake & Foto & Fotokake \\
\hline -ake & Gawe & Gawekake \\
\hline -ake & Gedhe & Gedhekake \\
\hline -ake & Bage & Begakake \\
\hline -ake & Blonyo & Blonyokake \\
\hline -ake & Bojo & Bojokake \\
\hline
\end{tabular}

Tabel 4. Morfofonemik Sufiks - ake 


\section{b. Pelesapan Fonem}

Menghilangnya salah satu fonem dalam suatu kata karena proses morfologi. Proses menghilangnya suatu fonem karena terjadi penggabungan antar morfem. Misalnya pada kata:

Cacah + e "angka atau jumlah" $\rightarrow$ Cacae "angkanya/jumlahnya"

Mbah + e "Kakek/Nenek" $\rightarrow$ Mbae "kakeknya/neneknya"

Omah + e "Rumah" $\rightarrow$ Omae "rumahnya"

Dakwah + e "sruan/ajakan" $\rightarrow$ Dakwae "seruannya"

Kumbah + e "Cuci" $\rightarrow$ Kumbae "cucinya"

Kuliyah + e "Kuliah/Sekolah" $\rightarrow$ Kuliae "Kuliahnya"

Pada contoh ini menampilkan pengilangan atau pelesapan fonem /h/ pada kata "cacah" dan kata "mbah" sebagai morfem dasar ketika ada afiksasi berupa sufiks $e$ sehingga menjadi "cacae" dan "mbae". Proses pengimbuhan sufiks "e" pada kata dasar ini, maka bunyi fonem /h/ yang ada dilesapkan.

\begin{tabular}{|l|l|l|}
\hline Sufiks & Kata Dasar & Morfofonologi \\
\hline$-e$ & Cacah & Cacae \\
\hline$-e$ & Mbah & Mbae \\
\hline$-e$ & Dakwah & Dakwae \\
\hline$-e$ & Kumbah & Kumbae \\
\hline$-e$ & Kuliyah & Kuliyae \\
\hline
\end{tabular}

Tabel 5. Morfofonemik Sufiks -e

Pelesapan fonem juga terjadi pada proses pengimbuhan perfiks berupa sufiks - an pada kata dasar jiwa, kwasa, jaga, kejaba, crita, bawa dan aniaya. Oleh karena itu bunyi atau fonem /a/ yang ada dilesapkan.

\begin{tabular}{|l|l|l|}
\hline Sufiks & Kata Dasar & Morfofonologi \\
\hline$-a n$ & Jiwa & Jiwan \\
\hline$-a n$ & Kwasa & Kwasan \\
\hline$-a n$ & Kejaba & Kejaban \\
\hline$-a n$ & Crita & Critan \\
\hline$-a n$ & Bawa & Bawan \\
\hline$-a n$ & Aniaya & Aniayan \\
\hline$-a n$ & Jaga & Jagan \\
\hline
\end{tabular}

Tabel 6. Morfofonemik Sufiks -an 


\section{c. Peluluhan Fonem}

Meluluhkan salah satu fonem dalam proses morfologi dengan memunculkan fonem yang lain.

Misalnya:

\begin{tabular}{|l|l|l|}
\hline Perfiks & Kata Dasar & Morfofonologi \\
\hline$P e-$ & Syukur & Penyukur \\
\hline$P e-$ & Kuwasa & Penguwasa \\
\hline$P e-$ & Temu & Penemu \\
\hline$N-$ & Cacah & Nyacah \\
\hline$N-$ & Cacar & Nyacar \\
\hline$N-$ & Cagak & Nyagak \\
\hline$N-$ & Cahak & Nyahak \\
\hline
\end{tabular}

Tabel 7. Morfofonemik Perfiks Pe-, Ny-

Pada bentuk morfofonemik bahasa Jawa terjadi peluluhan fonem melalui proses afiksasi, yaitu berupa prefiks atau ater-ater, dalam bahasa Jawa. Prefiks ini seperti pe- dengan kata dasar "syukur". Fonem awal pada kata dasar tersebut /s/ mengalami peluluhan, dari pe- + syukur menjadi "penyukur". Dan perubahan fonem /n/ menjadi /ny/. Demikian juga pada kata kuwasa dan temu yang berawalan fonem $/ \mathrm{k} /$ dan $/ \mathrm{t} /$. Peluluhan fonem ini juga terjadi pada kata yang berawalan bunyi /c/ dengan perfiks $\mathrm{N}$-y, seperti kata "cacah" menjadi "nyacah" dengan meluluhkan bunyi /c/.

\begin{tabular}{|l|l|l|}
\hline Perfiks & Kata Dasar & Morfofonologi \\
\hline $\mathrm{Me}$ & Kaji & Mengaji \\
\hline $\mathrm{Ng}-$ & Kethok & Ngethok \\
\hline $\mathrm{Ng}-$ & Kuliyah & Nguliyah \\
\hline $\mathrm{Ng}-$ & Kumbah & Ngumbah \\
\hline
\end{tabular}

Tabel 7. Morfofonemik Perfiks $\mathrm{Me}$-, $\mathrm{Ng}$ -

Demikian pula afiksasi berupa perfiks me-, dan ng-, meluluhkan bunyi fonem / k sehingga menjadi "mengaji", "ngethok", "nguliyah", dan "ngumbah" yang memiliki bunyi pertama pada kata dasar berupa bunyi $/ \mathrm{k} /$. 


\section{d. Pergeseran Fonem}

Perubahan Fonem mencakup reduplikasi dwipurwa dan reduplikasi dwilingga. Reduplikasi dwilingga terdapat perubahan fonem yang disebabkan oleh adanya upaya pelemahan, yaitu perubahan ke arah vokal yang di bawah sehingga lebih mudah untuk diucapakn. Misalnya sebagai berikut:

\begin{tabular}{|l|l|}
\hline Kata Dasar & Morfofonologi \\
\hline Kocar & Kacir \\
\hline Pontang & Panting \\
\hline Wira & Wiri \\
\hline Bolak & Balek \\
\hline Rono & Rene \\
\hline Mobrak & Mabrik \\
\hline Modhal & Madhul \\
\hline Oklak & Aklik \\
\hline Ngolak & Alik \\
\hline Othak & Athik \\
\hline
\end{tabular}

Tabel 8. Morfofonemik Pergeseran Fonem; Reduplikasi Dwilingga

Demikian pula pada perubahan fonem berupa reduplikasi dwipurwa, perubahan yang disebabkan oleh adanya upaya pelemahan vokal melalui pola vokal yang tegang, berposisi ucap yang rendah. Misalnya sebagai berikut:

\begin{tabular}{|l|l|}
\hline Kata Dasar & Morfofonologi \\
\hline Bakul & Bebakhulan \\
\hline Bareng & Bebarengan \\
\hline Basa & Bebasan \\
\hline
\end{tabular}

Tabel 9. Morfofonemik Pergeseran Fonem; Reduplikasi Dwipurwa

\section{Proses Morfofonemik Bahasa Arab}

\section{a. Pelesapan Fonem}

\begin{tabular}{|c|c|}
\hline Kata Dasar & Morfofonologi \\
\hline يَ يَوْعِدُ & يَعِدُ \\
\hline أَأَمَنَ & أَمَنَن \\
\hline قَقُوْتُ & قُمْتُ \\
\hline خِيْنْتُ & خِفْتُ \\
\hline
\end{tabular}




\begin{tabular}{|l|l|}
\hline أُدْعُوْ & \multicolumn{1}{|c|}{} \\
\hline
\end{tabular}

Tabel 10. Morfofonemik Pelesapam Fonem Bahasa Arab

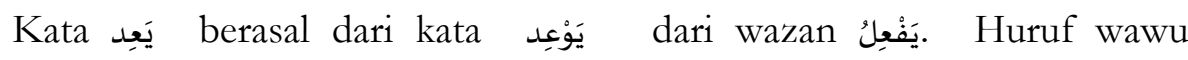
dihilangkan karena berada di antara harakat fathah dan harakat kasrah hakiki, sedangkan huruf wawu didahului oleh huruf mudhori' maka kata يَوْعِ berubah

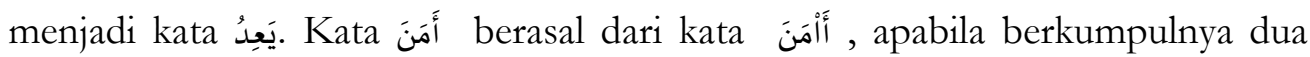
hamzah dalam satu kata maka hamzah kedua disukunkan atau dihilangkan. Jadi

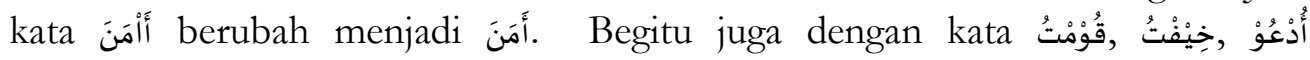
mengalami pelesapan fonem yaitu wawu, dan ya' dihilangkan sehingga berubah

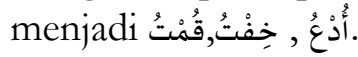

\section{b. Penambahan Fonem}

\begin{tabular}{|c|c|}
\hline Kata Dasar & Morfofonologi \\
\hline كَسَرَ & إنـكَسَرَ \\
\hline قَطَطَ & إنْقَطَطَ \\
\hline قََتَلَ & قَََاتَلَ \\
\hline أَجَابَ & إستنَجَجَابَ \\
\hline ضَرَرَبَ & إضضْطَرَبَ \\
\hline
\end{tabular}

Tabel 11. Morfofonemik Penambahan Fonem Bahasa Arab

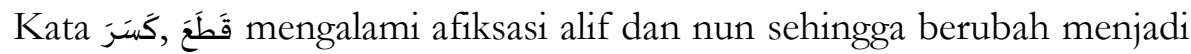

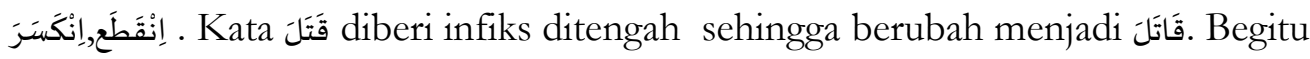

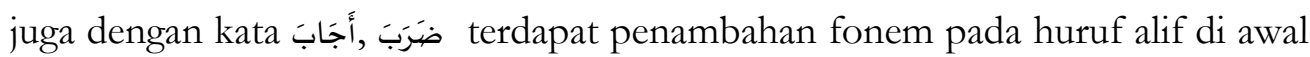
dan huruf tha' di tengah sehingga berubah menjadi kata إضْطَرَبَ ,إِنَتَجَابَ

c. Perubahan Fonem

\begin{tabular}{|c|c|}
\hline Kata Dasar & Morfofonologi \\
\hline صَبَرَ & إِصْطَبَرَ \\
\hline جَمَعَ & إِجْتَمَعَ \\
\hline إِيْتَسَرَ & إتَسَترَ \\
\hline إِوتَفَقَ & إتَفَقَ \\
\hline قَوَوَ & قَوَِيَ \\
\hline بَيَعَ & بَاعَ \\
\hline
\end{tabular}

Tabel 12. Morfofonemik Perubaban Fonem Babasa Arab

Proses morfofonemik dengan menggunakan infiks atau sisipin di tengah

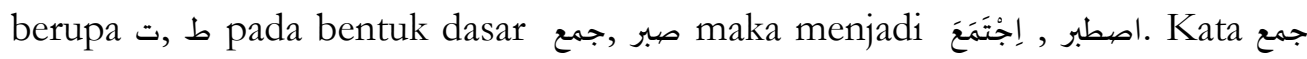

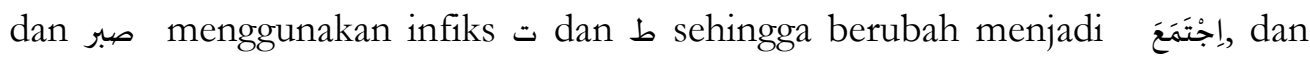


ايتسر اوتفق Mata kerja افتعل Mang berwazan اصبر . Kalami perubahan yaitu huruf و berubah menjadi ta' sukun, kemudian ta' pertama didghamkan pada ta' ke dua sehingga kata kerja tersebut berubah menjadi اتسر , اتفق.

\section{d. Pergeseran Fonem}

\begin{tabular}{|c|c|}
\hline Kata Dasar & Morfofonologi \\
\hline يَقْوُمُ & يَقُؤُمُ \\
\hline يَزُوُوُر & يَزُوْرُ \\
\hline يَبْيعُ & يَبِيْعُ \\
\hline يَبْبْنُ & يَبِيْنُ \\
\hline أَقَقََْمَ & أَقَامَ \\
\hline
\end{tabular}

Tabel 13. Morfofonemik Pergeseran Fonem Bahasa Arab

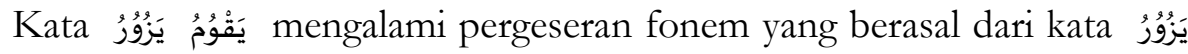
يَقْوُمُ dari wazan يَفْعُلُ . Harakat wawu dipindahkan kepada harakat huruf sebelumnya, begitu juga sebaliknya untuk menghindari beratnya pengucapan.

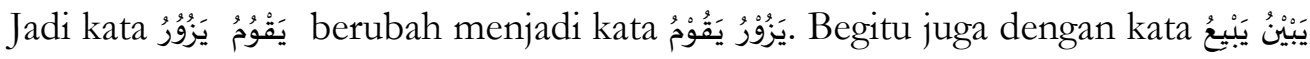
harakat ya' dipindakan kepada harakat sebelumnya. Kata أَقْوَمَ juga mengalami pergeseran fonem wawu dipindahkan kepada harakat sebelumnya kemudian disukunkan maka berubah menjadi أَقَامَ

\section{Analisis Kontrastif Proses Morfofonemik Bahasa Jawa dan Bahasa Arab}

Hasil penelitian yang dilakukan oleh Gunarsih menunjukkan bahwa kesamaan antara bahasa Jawa dan Arab dalam proses morfofonemik yaitu samasama terjadi dalam satu kata. Sedangkan perbedaan antara keduanya yaitu proses morfofonemik dalam Bahasa Jawa karena proses imbuhan pada morfem bebas. Adapun dalam bahasa Arab dikenal dengan nama i'lal dan ibdal. Probelem yang sering dihadapi oleh para siswa adalah dalam mengi'lalkan dan mengkategorikan lafal, sehingga diperlukan metode yang paling efektif dalam mempelajari morfofonemik bahasa Arab yaitu dengan drill atau latihan-latihan yang sesuai dengan kaedeh yang benar.

Analisis kontrastif merupakan metode yang tepat untuk membandingkan antara sistem bahasa satu dengan bahasa yang lain. ${ }^{8}$ Penggunaan analisis kontrastif ini perlu diperhatikan dua hal, yaitu prosedur kerja berupa membandingkan dua sistem bahasa dan tujuan penggunaan analisis kontrastif.

\footnotetext{
${ }^{7}$ Gunarsih, "Proses Morfofonemik Dalam Bahasa Indonesia Dan Bahasa Arab."

8 Maman Abdurrahman, "Analisis Kontrastif Klausa Verbal Bahasa Arab Dan Bahasa Indonesia Serta Implikasinya Dalam Pengajaran Nahwu,” Adabiyyat XI, no. 2 (2012).

9 Kasno Atmo Sukarto, "Analisis Kontrastif Sistem Morfemis Nomina Bahasa JawaIndonesia," Sawomanila, n.d., 91-100.
} 
Berdasarkan identifikasi terhadap proses morfofonemik bahasa Jawa dan bahasa Arab, dapat diketahui bahwa pembentukan kata pada kedua bahasa tersebut berasal dari dua morfem. Perubahan fonem yang muncul pada bahasa Jawa yaitu pada imbuhan di depan kata dasar (perfiks) pan- yang selanjutnya terjadi memunculkan fonem baru berupa /ng/ pada kata dasar berawalan fonem /a/.

Demikian pula konfiks pa-an pemunculan fonem baru pada kata dasar berawalan fonem $/ \mathrm{b} /$ yang memunculkan fonem baru berupa $/ \mathrm{m} /$. Sufiks $-\mathrm{i}$ pada kata dasar yang berakhiran fonem vokal /a/ dan /i/ menghasilkan fonem baru berupa /n/. Sedangkan sufiks -ake pada kata dasar berakhiran fonem /e/ dan $/ \mathrm{o} /$ memunculkan fonem baru $/ \mathrm{k} /$. Selain pemunculan fonem baru, morfofonemik bahasa Jawa juga terjadi melalui pelesapan fonem dengan sufiks e dan sufiks -a yang melesapkan fonem akhir /h/ dan /a/ pada suatu kata dasar. Peluluhan terjadi melaui konfiks pe-n yang meluluhkan fonem awal /s/,/k/,/t/ pada setiap kata dasar yang akhirnya meluluh menjadi /ny/. Perfiks $\mathrm{n}$ - pada fonem awal kata dasar berupa /c/ meluluhkan fonem menjadi /y/. Peluluhan juga pada perfiks me-, ng- yang meluluhkan awalan fonem kata dasar berupa $/ \mathrm{k} /$. Sedangkan pergeseran fonem ke vokal yang di bawah lebih mudah diucapkan, seperti dari fonem /a/ ke /i/, /a/ ke /e/, /o/ ke/e/, /a/ ke /u/, dan $/ \mathrm{a} / \mathrm{ke} / \mathrm{i} /$.

Morfofonemik dalam bahasa Arab salah satunya terjadi dengan peluluhan fonem. Fonem wawu diluluhkan karena berada di antara harakat fathah dan harakat kasrah hakiki. apabila berkumpulnya dua hamzah dalam satu kata maka hamzah kedua disukunkan atau dihilangkan. Sedangkan penambahan fonem melalui afiksasi berupa perfiks alif ataupun infiks ta pada setiap kata dasar. Pergeseran fonem termasuk proses morfofonemik yang ada pada bahasa Arab. Harakat wawu dipindahkan kepada harakat huruf sebelumnya, begitu juga sebaliknya untuk menghindari beratnya pengucapan. Sedangkan perubahan fonem pada proses morfofonemik bahasa Arab dengan menggunakan infiks atau sisipin di tengah berupa ط طبر , جمع mada bentuk dasar menjadi

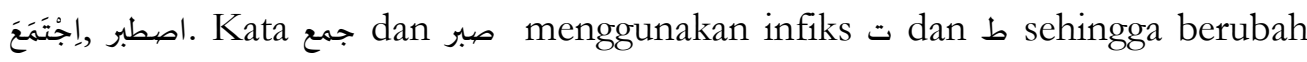

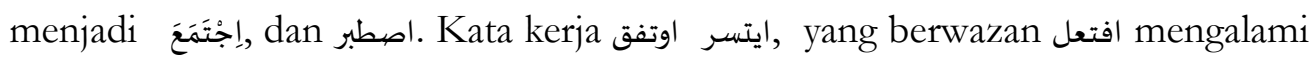
perubahan yaitu huruf, berubah menjadi ta' sukun, kemudian ta' pertama didghamkan pada ta' ke dua sehingga kata kerja tersebut berubah menjadi اتفقر, اتسر

\section{Penutup}

Kajian tentang analisis kontrastif morfofonologi bahasa Jawa dan bahasa Arab ini memberikan kontribusi atau sumbangan terhadap para pembelajar bahasa asing; bahasa Arab dalam mempelajari dan menguasai bahasa tersebut; perubahan kata dengan membandingkan bahasa ibu;bahasa Jawa. Ke depan, 
kajian tentang analisis kontrastif morfofonologi ini, sebaiknya muncul penelitian yang lebih mendalam lagi guna memperkaya dan memperdalam kajian kontrastif morfofonologi.

\section{Bibliografi}

Abdurrahman, Maman. "Analisis Kontrastif Klausa Verbal Bahasa Arab Dan Bahasa Indonesia Serta Implikasinya Dalam Pengajaran Nahwu." Adabiyyat XI, no. 2 (2012).

Amrulloh, Muhammad Afif. "Taghyiru Soutiyat Al-Lughah Al-'Arabiyyah AlMusta'arah Fi Al-Lughah Al-Jawiyyah." Al Bayan: Jurnal Jurusan Pendidikan Bahasa Arab 8, no. 2 (2016).

Dimyati, Farida Kusuma. "Proses Morfofonemik Dalam Bahasa Inggris Dan Bahasa Gorontalo (Suatu Analisis Kontrastif)," 2014.

Gunarsih. "Proses Morfofonemik Dalam Bahasa Indonesia Dan Bahasa Arab." IAIN Sunan Kalijaga Yogyakarta, 2002.

Subiyanto, Agus. "Proses Fonologis Bahasa Jawa: Kajian Teori Optimalitas." Babasa Dan Seni, no. 2 (2010): 154-65.

Suherman. "Perubahan Fonologis Kata-Kata Serapan Bahasa Sunda Dari Bahasa Arab: Studi Kasus Pada Masyarakat Sunda Di Jawa Barat, Indonesia." Sosiohumanika 5, no. 1 (2012).

Sukarto, Kasno Atmo. "Analisis Kontrastif Sistem Morfemis Nomina Bahasa Jawa-Indonesia." Sawomanila, n.d., 91-100.

Sundasewu, Rama Ulun. "Analisis Kontrastif Perubahan Fonem Pada Proses

Reduplikasi Dalam AHASBahasa Jepang Dan Bahasa Indonesia: Kajian Morfofonemik." Jurnal Ilmu Pendidikan Dan Pengajaran 2, no. 2 (2015). 